\title{
Article \\ Oral Health Related Behaviors in Relation to DMFT Indexes of Teenagers in an Urban Area of North-West Poland-Dental Caries Is Still a Common Problem
}

\author{
Marta Milona ${ }^{1, *}$, Joanna Janiszewska-Olszowska ${ }^{2}$, , Monika Szmidt ${ }^{3}$, Karolina Kłoda ${ }^{4}$ (D) \\ and Tomasz Olszowski ${ }^{1}$
}

check for

updates

Citation: Milona, M.;

Janiszewska-Olszowska, J.; Szmidt,

M.; Kłoda, K.; Olszowski, T. Oral

Health Related Behaviors in Relation to DMFT Indexes of Teenagers in an Urban Area of North-West Poland-Dental Caries Is Still a Common Problem. Int. J. Environ. Res Public Health 2021, 18, 2333. https:// doi.org/10.3390/ijerph18052333

Academic Editor: Gianrico Spagnuolo

Received: 18 January 2021

Accepted: 22 February 2021

Published: 27 February 2021

Publisher's Note: MDPI stays neutral with regard to jurisdictional claims in published maps and institutional affiliations.

Copyright: (c) 2021 by the authors. Licensee MDPI, Basel, Switzerland. This article is an open access article distributed under the terms and conditions of the Creative Commons Attribution (CC BY) license (https:// creativecommons.org/licenses/by/ $4.0 /)$.
1 Department of Hygiene and Epidemiology, Pomeranian Medical University in Szczecin, 70-111 Szczecin, Poland; tomasz.olszowski@pum.edu.pl

2 Department of Interdisciplinary Dentistry, Pomeranian Medical University in Szczecin, 70-111 Szczecin, Poland; jjo@pum.edu.pl

3 Department of Conservative Dentistry with Endodontics, Pomeranian Medical University in Szczecin, 70-111 Szczecin, Poland; monika@inet.pl

4 Medfit Karolina Kłoda, 70-240 Szczecin, Poland; wikarla@gazeta.pl

* Correspondence: marta.milona@pum.edu.pl

\begin{abstract}
Caries has a negative influence on health and is still a public health problem among children and adolescents in Poland. The aim of this study was to analyze the association of dietary habits, oral hygiene behaviors and the frequency of usage of dental services with the dental caries index in teenagers in North-West Poland. The study enrolled 264 children (147M/117F) aged 15. Participants filled out a questionnaire regarding age, sex, frequency of visits to the dentist, dietary habits and oral hygiene behaviors, and the Decayed Missing Filled Teeth Index (DMFT) was calculated. Caries was found in $88.6 \%$ of subjects. The lower or no caries experience group (DMFT $\leq 5$ ) comprised of 180 subjects, while higher caries experience (DMFT > 5) was found in 84 teenagers and was significantly inversely associated with tooth brushing after the last meal (OR $=0.45 ; 95 \%$ CI:0.21-0.97; $p=0.04$ ) and the daily use of dental floss (OR $=0.12 ; 95 \% \mathrm{CI}: 0.01-0.92 ; p=0.04)$. There is an emerging need for the implementation of effective caries prevention and recovery programs in Poland. Health promotion focusing on oral hygiene behaviors should be disseminated more widely because lower caries experience was demonstrated in teenagers declaring healthy oral habits. Another important need is the development of multi-sectorial actions aiming at the improvement of dietary habits.
\end{abstract}

Keywords: adolescents; caries; oral hygiene; teenagers; urban area

\section{Introduction}

Caries is the most prevalent disease amongst children and adolescents, which has a negative influence on health [1]. In the second half of the 20th century, it was considered to be an infectious disease. Nowadays, it is regarded to have a complex nature with an important role of the biofilm and behavioral as well as with socio-economic factors (or confounders) which influence the likelihood for lesion development [2]. Thus, this multifactorial nature requires the implementation of effective preventive measures at social, school, family, individual and population levels [3].

Dental caries, gingival diseases and periodontal diseases are chronic and occur commonly in children, but are preventable $[4,5]$. These conditions are more prevalent within marginalized populations and disadvantaged communities [6]. At an individual level, risk factors include dietary patterns, oral health behaviors and practices, together with the use of dental care. The composition of meals and the frequency of food intake are considered to be the strongest factors associated with the cariogenic effect of the diet. The frequent consumption of products containing sugars, especially between meals, contributes to the increase in caries prevalence, particularly in people with poor oral hygiene [7-9]. 
Modern preventive programs are directed at children and adolescents and focus on the formation of correct eating habits, including the limitation of sugar consumption together with the promotion of anti-plaque cleaning activities. The most important are regular tooth brushing with fluoride toothpaste and cleaning the proximal surfaces of the teeth [10,11].

For many years, there has been no complex dental prophylaxis program in Poland, enabling children and young people to obtain at least, discussed below, an average oral health level for the European Union (EU). The Polish Government statistic materials show that the frequency of dental caries in 12-year-old children is $85 \%$, and their Decayed Missing Filled Teeth (DMFT) index is 3.8, while in 15-year-olds it is $94 \%$ and their DMFT is 5.65 [12]. These are some of the worst results in the EU.

The aim of the present study was to analyze the association of dietary habits, oral hygiene behaviors and the frequency of usage of dental services with the dental caries index in teenagers in North-West Poland.

\section{Materials and Methods}

The study comprised of 264 children (147 boys and 117 girls) aged 15, attending public lower secondary schools in the system of obligatory general education, in the city of Szczecin, northwestern Poland. Schools $(n=10)$ included in the study were located in different districts (North, South, East, West, Downtown) and were randomly drawn from the list of public gymnasiums $(n=37)$. Such a list was placed on the website of the Department of Education of the Szczecin Municipal Office under the link "List of public schools and educational units in Szczecin". The randomization was performed with use of a random numbers table. In the second stage of the procedure, one class, out of the whole year, was selected by the same method. The protocol of the study was approved by the Bioethics Committee of the Pomeranian Medical University (decision reference No. KB-0012/81/14).

Each participant and their guardian gave written consent for participation in this study. Other details concerning the study subjects' recruitment and their clinical dental examination have been described in our previous paper [13]. The Decayed Missing Filled Teeth Index (DMFT) was calculated in every child as the sum of decayed (D), missing due to caries $(\mathrm{M})$ and filled teeth $(\mathrm{F})$. This was performed by visual-tactile examination [14]. Adolescents were examined by the same dentist and the test result was marked directly on the individual study card. The detection of open cavities was based on visual inspection of the dental surfaces with the aid of a dental lamp and dental mirror. A dental probe was used to remove plaque that could be covering a lesion, and then the blunt side of the probe was used to assess the surface roughness and to check for signs of enamel breakdown. The white spot lesion was considered as a healthy tooth. Children with moderate or high caries experience with a DMFT $>5$ were assigned to the "higher caries experience" group, while those with low or very low caries experience (DMFT $\leq 5)$ were assigned to the "lower caries experience" group [15]. The Significant Caries Index ( $\mathrm{SiC}$ Index) was calculated as follows: individuals were sorted according to their DMFT values. One third of the population with the highest caries scores were selected, according to Bratthl [16]. The mean DMFT for this subgroup was calculated. In addition, all the teenagers filled out a questionnaire containing questions about age, sex, frequency of visits to the dentist, dietary habits and oral hygiene behaviors. Dietary habits analyzed included the frequency of consumption of sweets, sweet drinks and snacks in separate ranges: at all, less frequently than once a week, once a week, 2-4 times a week, once a day, more often than once a day. Health behaviors related to oral hygiene have been evaluated based on answers to questions about the time and frequency of brushing teeth, the use of dental floss, and the use of interdental brushes, irrigators, toothpicks and mouthwashes. The entire questionnaire is listed in Table 1.

The tap water in Szczecin, which is drinkable, is not artificially fluoridated: the mean fluoride concentration ranges from 0.11 to $0.25 \mathrm{mg} / \mathrm{L}$ (data obtained from the Municipal Sanitary Epidemiological Inspectorate). 
Table 1. The questionnaire form.

\begin{tabular}{|c|c|}
\hline 1 & $\begin{array}{c}\text { How often do you brush your teeth? } \\
\text { less than once a day } \\
\text { once a day } \\
\text { twice a day } \\
\text { after each meal }\end{array}$ \\
\hline 2 & $\begin{array}{c}\text { In the morning I brush my teeth: } \\
\text { before breakfast } \\
\text { after breakfast } \\
\text { I do not brush my teeth at all } \\
\text { I just rinse my mouth }\end{array}$ \\
\hline 3 & $\begin{array}{c}\text { After the last evening meal before bedtime } \\
\text { I do not perform any oral hygiene procedures } \\
\text { I just rinse my mouth } \\
\text { I brush my teeth thoroughly }\end{array}$ \\
\hline 4 & $\begin{array}{l}\text { I use for oral hygiene additionally (apart from toothbrush and toothpaste) } \\
\text { dental floss } \\
\text { interdental toothbrush } \\
\text { irrigator } \\
\text { mouthwash } \\
\text { toothpicks } \\
\text { none }\end{array}$ \\
\hline 5 & $\begin{array}{l}\text { I use dental floss } \\
\text { never } \\
\text { less than once a week } \\
1-4 \text { times a week } \\
\text { once a day } \\
\text { more than once a day }\end{array}$ \\
\hline 6 & $\begin{array}{l}\text { I replace my toothbrush } \\
\text { once a year } \\
\text { every } 6 \text { months } \\
\text { every } 3 \text { months } \\
\text { every month }\end{array}$ \\
\hline 7 & $\begin{array}{l}\text { I eat sweets } \\
\text { never } \\
\text { less than once a week } \\
\text { once a week } \\
2-4 \text { times a week } \\
\text { once a day } \\
\text { more than once a day }\end{array}$ \\
\hline 8 & $\begin{array}{l}\text { I eat snacks, breadsticks, crackers } \\
\text { never } \\
\text { less than once a week } \\
\text { once a week } \\
2-4 \text { times a week } \\
\text { once a day } \\
\text { more than once a day }\end{array}$ \\
\hline 9 & $\begin{array}{l}\text { I drink soft drinks } \\
\text { never } \\
\text { less than once a week } \\
\text { once a week } \\
\text { 2-4 times a week } \\
\text { once a day } \\
\text { more than once a day }\end{array}$ \\
\hline 10 & $\begin{array}{c}\text { I visit the dental office } \\
\text { only when I feel toothache } \\
\text { only when I notice a cavity in my tooth } \\
\text { every } 6 \text { months }\end{array}$ \\
\hline
\end{tabular}


The results were statistically analyzed using Statistica 11 software (TIBCO Software Inc., Palo Alto, CA, USA). The comparisons of the median values of the index, according to gender, were made using the Mann-Whitney test. The evaluation of the statistical significance of differences between mean frequencies was generated using the chi-square test with Yates correction factor or the Fisher's exact test. The logistic regression method was performed to identify the predictors of dental caries experience using a free statistics program [17]. The backward elimination method was used to select variables for the logistic regression model. The level of significance has been established at $p=0.05$.

\section{Results}

Prevalence and caries experience (DMFT and $\mathrm{SiC}$ ) in the studied 15-year-olds are presented in Table 2.

Table 2. Caries experience (DMFT, SiC) among 15-year-old teenagers in Szczecin.

\begin{tabular}{|c|c|c|c|c|}
\hline & Total N 264 (100\%) & Males N 147 (100 \%) & Females N 117 (100\%) & $p$ Value * \\
\hline $\begin{array}{l}\text { Subjects with caries experience } \\
(\text { DMFT }>0)\end{array}$ & $233(88.3 \%)$ & $131(89.1 \%)$ & $102(87.2 \%)$ & \\
\hline Mean DMFT & 4.1 & 4.1 & 4.2 & 0.78 \\
\hline $\begin{array}{l}\text { Number of subjects with moderate } \\
\text { and high caries experience } \\
(\mathrm{DMFT}>5)\end{array}$ & $84(31.8 \%)$ & $46(31.2 \%)$ & $38(32.4 \%)$ & \\
\hline $\mathrm{SiC}$ & 7.5 & 7.4 & 7.6 & 0.8 \\
\hline
\end{tabular}

* Mann-Whitney test, DMFT—Decayed Missing Filled Teeth Index, SiC—Significant Caries Index.

In the present study, caries was found in $88.3 \%$ of subjects. In males, the mean DMFT was 4.1 and in females it was 4.2 , with no significant difference $(p=0.78)$. Moderate and high caries (DMFT > 5) experience was found in $84(31.8 \%)$ teenagers $(31.2 \%$ males and $32.4 \%$ females), while low or very low caries experience (DMFT $\leq 5$ ) was found in 180 $(68.2 \%)$ subjects. The $\mathrm{SiC}$ index was 7.5 , not differing significantly between the sexes. Oral health behaviors in relation to caries experience are presented in Table 3.

Table 3. Oral health behaviors and dietary habits in relation to caries experience of 15-year-old teenagers in Szczecin.

\begin{tabular}{|c|c|c|c|c|}
\hline & $\begin{array}{l}\text { Total } N=264 \\
(100 \%)\end{array}$ & $\begin{array}{c}\text { DMFT } \leq 5 \mathrm{~N}=180 \\
(\mathbf{1 0 0 \% )}\end{array}$ & $\begin{array}{c}\text { DMFT }>5 N=84 \\
(100 \%)\end{array}$ & $p$ Value * \\
\hline $\begin{array}{l}\text { Tooth brushing } \\
\text { twice daily or more often } \\
\text { after breakfast } \\
\text { after last meal before bedtime } \\
\text { toothbrush replacement at least every } 3 \text { months }\end{array}$ & $\begin{array}{c}217(82 \%) \\
172(65.1 \%) \\
231(87.5 \%) \\
204(77.2 \%)\end{array}$ & $\begin{array}{c}153(85 \%) \\
121(67.2 \%) \\
163(91 \%) \\
144(80 \%)\end{array}$ & $\begin{array}{l}64(76.2 \%) \\
51(60.7 \%) \\
68(81 \%) \\
60(71.4 \%)\end{array}$ & $\begin{array}{l}0.12 \\
0.37 \\
0.05 \\
0.16\end{array}$ \\
\hline $\begin{array}{l}\text { The use of auxiliary oral hygiene aids } \\
\text { dental floss } \\
\text { dental floss every day } \\
\text { mouthwash } \\
\text { toothpicks }\end{array}$ & $\begin{array}{c}118(45 \%) \\
19(7 \%) \\
145(54.9 \%) \\
39(15.9 \%)\end{array}$ & $\begin{array}{l}86(47.8 \%) \\
18(10 \%) \\
99(55 \%) \\
27(15 \%)\end{array}$ & $\begin{array}{c}32(38 \%) \\
1(1.2 \%) \\
46(54 \%) \\
12(14.3 \%)\end{array}$ & $\begin{array}{l}0.18 \\
0.01 \\
0.92 \\
0.99\end{array}$ \\
\hline $\begin{array}{l}\text { Dietary habits } \\
\text { sweets once a week or less } \\
\text { sweets once daily or more } \\
\text { snacks once a week or less } \\
\text { snacks once daily or more } \\
\text { soft drinks once a week or less } \\
\text { soft drinks once daily or more }\end{array}$ & $\begin{array}{c}62(23.5 \%) \\
112(42.4 \%) \\
212(80.3 \%) \\
16(6.1 \%) \\
166(62.9 \%) \\
41(15.5 \%)\end{array}$ & $\begin{array}{c}47(26.1 \%) \\
72(40 \%) \\
145(80.6 \%) \\
12(6.7 \%) \\
120(66.7 \%) \\
29(16.1 \%)\end{array}$ & $\begin{array}{c}15(17.9 \%) \\
40(47.6 \%) \\
67(79.8 \%) \\
4(4.8 \%) \\
46(54.8 \%) \\
12(14.3 \%)\end{array}$ & $\begin{array}{c}0.19 \\
0.3 \\
0.99 \\
0.74 \\
0.08 \\
0.84\end{array}$ \\
\hline $\begin{array}{l}\text { Visiting the dentist } \\
\text { just in case of pain or when I notice a cavity in a } \\
\text { tooth } \\
\text { control visit once every six months }\end{array}$ & $\begin{array}{c}49(18.6 \%) \\
153(57.9 \%)\end{array}$ & $\begin{array}{c}34(18.9 \%) \\
109(60.5 \%)\end{array}$ & $\begin{array}{l}15(17.8 \%) \\
44(52.4 \%)\end{array}$ & $\begin{array}{l}0.98 \\
0.26\end{array}$ \\
\hline
\end{tabular}


Most teenagers ( $82 \%$ ) brushed their teeth at least twice a day. Females, as compared to males, had significantly higher odds of performing oral hygiene habits, such as toothbrushing twice a day $(\mathrm{OR}=11.68 ; 95 \% \mathrm{CI}: 4.05-33.66 ; p=0.000001)$ and brushing their teeth after their last meal before bedtime (OR $=9.74 ; 95 \%$ CI: 2.89-32.82; $p=0.00008$ ) (see Table 3 ). There was no statistical significant difference between the sexes $(p=0.13)$ regarding toothbrush replacement. The frequency of toothbrush replacement (at least every 3 months) had no influence on DMFT $(p=0.16)$. Similarly, subjects toothbrushing at least twice a day did not have a significantly lower DMFT than those brushing their teeth less frequently $(p=0.12)$. In order to maintain oral hygiene, the teenagers examined used mouthwash $(54.9 \%)$ and dental floss $(45 \%)$ the most often (see Table 3$)$. Dental floss was used statistically more often by the girls (OR $=2.36 ; 95 \%$ CI: $1.44-3.89 ; p=0.0009)$, and the boys were more likely to reach for toothpicks (OR $=0.38 ; 95 \%$ CI: $0.18-0.82 ; p=0.02$ ) (Table 4$)$. The logistic regression model revealed two significant predictors of "higher" caries experience: tooth brushing after the last meal and the daily use of dental floss (Table 5). Among the examined teenagers, "higher" caries experience (DMFT > 5) was significantly inversely associated with toothbrushing after the last meal (OR $=0.45 ; 95 \% \mathrm{CI}: 0.21-0.97 ; p=0.04)$ and the daily use of dental floss (OR $=0.12 ; 95 \%$ CI: $0.01-0.92 ; p=0.04)$. Over $40 \%$ of adolescents ate sweets at least once a day, and $15.5 \%$ drank sweet sodas at least once a day. Girls $(73.5 \%)$, more often than boys $(54.4 \%)$, limited the drinking of sugary soft drinks to at most one day a week $(p=0.002)$. Subjects eating sweets $(p=0.19)$ or drinking soft drinks $(p=0.08)$ once a week or less frequently were not characterized by a significantly lower DMFT (see Table 3). Only $57.9 \%$ of the surveyed youth reported regularly for dental check-ups, and $18.6 \%$ declared that they visit the dental office only in the case of pain or when they noticed a cavity in a tooth. There were no significant differences in reporting for dental visits referring to gender or caries experience. Gender differences in selected oral health behaviors and dietary habits in a group of 15-year-old teenagers in Szczecin are presented in Table 4.

Table 4. Gender differences (Females vs. Males) in selected oral health and dietary habit behaviors of 15-year-old teenagers in Szczecin.

\begin{tabular}{lcc}
\hline \multicolumn{1}{c}{ Risk Factor } & OR (95\%CI) & $p$ Value * \\
\hline Tooth brushing twice or more per day & $11.68(4.05-33.66)$ & 0.000001 \\
Tooth brushing after last meal before bedtime & $9.74(2.89-32.82)$ & 0.00008 \\
Using dental floss & $2.36(1.44-3.89)$ & 0.0009 \\
Using toothpick & $0.38(0.18-0.82)$ & 0.02 \\
Soft drinks once a week or less & $2.32(1.34-4.07)$ & 0.002 \\
\hline
\end{tabular}

*Fisher exact test.

Table 5. Logistic regression model describing the predictors of "higher" caries experience (DMFT > 5) among the examined 15-year-old teenagers in Szczecin.

\begin{tabular}{lcc}
\hline \multicolumn{1}{c}{ Variable } & OR (95\%CI) & $p$ Value \\
\hline Tooth brushing after last meal before bedtime & $0.45(0.21-0.97)$ & 0.04 \\
Using dental floss every day & $0.12(0.01-0.92)$ & 0.04 \\
\hline
\end{tabular}

Overall Model Fit Chi square $=12.79 p=0.001$.

\section{Discussion}

This study focused on the association of dietary habits, oral hygiene behaviors and the frequency of usage of dental services with the dental caries index in teenagers inhabiting North-West Poland. Alarming observations from our study show that caries is still a common problem in this part of Central Europe. We have confirmed that the oral hygiene behaviors of the studied adolescents are of tremendous importance for their oral health Tooth brushing after the last meal and the daily use of dental floss were the two significant inverse predictors of "higher" caries experience. Moreover, poor dietary habits (over 40\% 
ate sweets at least once a day) and inadequate usage of dental service (18.6\% visit the dental office only in the case of pain or noticing a cavity) are additionally contributing to the amount of $88.3 \%$ of teenagers with caries in our study.

The age of adolescence is important for the formation of positive oral hygiene habits that would be replicated in adult life. It is also a time when children start presenting oppositional behaviors towards parents and teachers, which may result in difficulties in effective health education [18]. Therefore, educational programs promoting desirable oral health behaviors are most effective if they are directed to children (and their parents) and people involved in their daily lives from the earliest school years. These programs must take into account the change of attitudes, behaviors and knowledge through a multi-level approach with the simultaneous wide use of social support $[19,20]$.

The oral health of children and adolescents in Poland, despite the improvement at the turn of the 20th and 21st centuries, has remained at a low level for a decade [21]. The dental care system in Poland guarantees free prevention to children, but dentists rarely use preventive interventions (professional tooth cleaning, individual use of fluoride, dietary advice, determining the level of oral hygiene, individual oral hygiene instructions) in practice [22]. While there is a lack of continuous, common, integrated and multi-faceted programs of oral health promotion that allow introducing and maintaining changes to teenagers' attitudes and behaviors, it is impossible to achieve oral health levels similar to their peers in EU countries [23]. In our study, 15-year-old children from North-West Poland were characterized by a lower DMFT compared to the result of nationwide data (4.1 vs. 5.8 (2015) or 6.1 (2011)), but the prevalence of caries was the same (88.3\% vs. 91.8\%) [24,25]. In comparison to such countries as Sweden, Germany or Great Britain, we have almost twice as many (88.6\%) 15-year-olds with obvious decay experience, and the DMFT indicator is almost three times higher (Sweden 1.2, Germany and Great Britain 1.4) [26,27]. In Great Britain, only $9 \%$ of respondents reported high caries experience (DMFT > 5), while in our study, $31 \%$ of teenagers reported high caries experience. In Swiss 15-year-olds, the SiC index was similar (4.39) to the level of our DMFT indicator (4.1) [28,29]. Lower rates have also been achieved by teenagers from Portugal (DMFT 2.5 and 32\% caries free), Greece (DMFT 3.19 and 29\% caries free) and Romania (DMFT 3.6 and 21.5\% caries free), as well as SOS Children's Village residents in Croatia (DMFT 1.61) [30-33]. A prevalence of caries similar to Poland in this age group was found in the youth of Bulgaria (91.5\%), Latvia $(92.9 \%)$ and the Czech Republic (86.4\%), with a DMFT of 5.0 in both the Czech Republic and Bulgaria, and 5.5 in Latvia [34].

Positive associations between free sugars intake and dental caries were found in all age groups (including $<5$ years to $>65$ years); in developing, transitional and industrialized countries. In general, the evidence suggests a positive relationship between the amount of free sugars consumption and dental caries, both in children and adults. According to a WHO report, the recommendation for free sugars intake was changed from the previous $10 \%(\mathrm{WHO}, 2003)$ to $5 \%$ of daily energy intake to reduce obesity and dental caries [8]. Free sugars include monosaccharides and disaccharides added to foods and beverages by the manufacturer, cook or consumer, and sugars that are naturally present in honey, syrups, fruit juices and fruit juice concentrates. As dental caries is the result of lifelong exposure to a dietary risk factor (free sugars), even a small reduction in the risk of dental caries in childhood is of significance to future dental health. Therefore, to minimize the lifelong risk of dental caries, free sugars intake should be as low as possible [35,36]. However, the mean sugar consumption in EU countries is high at $39.0 \mathrm{~kg} /$ person/year, and in Poland, it is high at $44.1 \mathrm{~kg} /$ year (2012 data) [37]. Many authors show a relationship between the frequency of consumption of sugary drinks/confection and enamel erosion [38-40].

There are only a few studies on the oral health behaviors of Polish teenagers (age 12-18 years), and unfortunately, commonly available knowledge is not reflected in their health habits. Only less than a quarter of the surveyed teenagers $(23.5 \%)$ in the present study limited their consumption of sweets to at most one day a week. Subjects with DMFT $<5$ limited their consumption of sweets more often $(26.1 \%)$ than those with high carious 
activity (17.9\%). We observed a similar trend when limiting sweet carbonated beverages: $62.9 \%$ of the respondents drank them once a week or less. A higher percentage of girls than boys (73.5\% vs. $54 \%$ ) and a higher percentage of children with lower caries experience compared than those with DMFT > $5(66.7 \%$ vs. $54.8 \%)$ reported drinking sweet carbonated beverages once a week or less. On the other hand, the percentage of young people who declared daily consumption of sweets was alarmingly high (42.4\%). Even against the background of the Polish authors' research, it was a very high result. In the nationwide survey it amounted to $25.3 \%$, and among teenagers from the Mazovian region, $22.8 \%$. Sugary drinks in our study were drunk by $15.5 \%$ teenagers daily compared to $20 \%$ in the nationwide survey and $17.7 \%$ in the Mazovian region [24,41]. The advantage of our study in comparison to earlier research is assessing not only oral health behaviors and dietary habits, but also performing clinical examination and associating the obtained findings. Moreover, data from North-West Poland were lacking.

School shops, prevalent in our country, may have had an influence in the strengthening of these negative habits. Eighty-eight percent of pupils had access to school shops in their schools, and their assortment was often limited to items considered highly cariogenic: confectionery (iced donuts, sweet cakes), sweets and chips, and sweetened beverages. Since September 2015, the Polish Government has introduced strict restrictions on the distribution of products containing sugar and sweeteners as defined in the Regulation of the European Parliament and Council No. 1333/2008, and on food additives in educational institutions, completely excluding confectionery and semi-confectionery products, sweetened breakfast cereals, and processed fruit and vegetables with the addition of sugar or sweeteners. Unfortunately, only one year later these restrictions were withdrawn [42,43]. This is the opposite direction to the recommendation regarding providing children in schools and pre-schools with access to meals and beverages, taking into account the latest health recommendations, and promoting a reduction in processed food [44]. It is therefore difficult to popularize the model of eating sweets one day a week by children and young people, which is widespread in many countries, especially Scandinavian countries. Due to this model, only $17 \%$ of twelve-year-olds in Finland and $14 \%$ of eighteen-year-olds in Norway eat sweets every day $[45,46]$.

Despite the obvious evidence that the consumption of larger amounts of total sugars, sugar-containing foods/beverages as well as the greater frequency of consumption of sugar-containing foods/beverages, but not the frequency of consumption of total sugars, is associated with a greater risk of dental caries, the importance of sugars as a cause of caries is not prominent in preventive strategies. This is despite overwhelming evidence of its unique role in causing a worldwide caries epidemic. The long-standing failure to identify the need for drastic national reductions in sugar intakes reflects scientific confusion, partly induced by pressure from major industrial sugar interests $[47,48]$. Unfortunately, Poland is listed among the countries with a high percentage of the population affected by dental caries and also by being overweight or obese.

Plaque is considered the most important risk factor for caries. Effective oral hygiene is a key factor in maintaining good oral health, and tooth brushing with fluoride toothpaste is thought the most important $[49,50]$. The addition of dental floss and an interdental brush to brushing effectively removes the plaque from the interdental spaces. This will allow a reduction in oral hygiene indexes, and it significantly reduces the occurrence of periodontal diseases [11,51]. According to our research, the percentage of 15-year-olds in Szczecin who brushed their teeth at least twice a day was surprisingly very high and amounted to $82 \%$, but only $7 \%$ used dental floss daily. However, in our study, the daily use of dental floss (OR 0.12; $p=0.04$ ) and tooth brushing after the last meal before bedtime (OR $0.45 ; p=0.04$ ) proved to be significant factors lowering the risk of higher caries experience (DMFT > 5). Similarly, Julihn et al. found that irregular toothbrushing in the evening was strongly associated with a high caries prevalence in 19-year-olds [52]. Additionally, recent evidence supports a recommendation that brushing with a fluoride toothpaste should take place just 
prior to going to bed; fluoride concentrations in saliva $12 \mathrm{~h}$ after brushing directly before bedtime were comparable with those found $1-4 \mathrm{~h}$ after brushing during the day [53].

According to the latest data, brushing teeth just as often as twice a day was declared by young people from Sweden (77-86\% girls and $71 \%$ boys) and Scotland ( $83 \%$ girls and $65 \%$ boys) [54,55]. Definitely lower rates of youths who brushed their teeth twice or more times a day were recorded in the Czech Republic (79.5\% girls and $61.9 \%$ boys), in France (70.9\%), in Portugal (65.1\%) and in Australia (57\%) [56-59]. In accordance with the results of other authors, we observed a significant difference between the genders referring to the frequency of toothbrushing [59-61]. Girls were brushing their teeth at least twice a day $(96.6 \%, p=0.0001)$ and before bedtime $(97.4 \%, p=0.0001)$ more often than boys. They used dental floss more often $(56.4 \%, p=0.001)$ as well. Additionally, in another study of 15-year-old youths from central Poland, the percentage of people brushing their teeth at least twice a day was lower (73.6\%) compared to the result of our study. However, the percentage of teenagers who used floss was similar (49.5\% vs. $45 \%$ ) [41], but studies by Polish authors in other regions showed even lower proportions of junior high school students using dental floss: 37\% [62] and 12.9\% [63]. The positive results we obtained in terms of the declared toothbrushing twice a day can be a sign of the superior knowledge of recommended/desirable health behaviors amongst our teenagers, but they do not necessarily reflect the actual attitudes.

Many authors believe that the attitude towards the use of dental services is dependent on economic conditions, the level of education and cultural determinants [64,65]. Early prevention and diagnosis of caries is a result of regular visits to a dentist. There was a significant relationship between the date of the first visit of a child and the costs of future treatment (i.e., an increase in costs with the time of the first visit being delayed) [66]. A visit to the dentist not only has a therapeutic aspect, but educational intervention conducted by health professionals, in the context of their practice, helps to promote oral health in the population [67-70]. Spanish children regularly attending dental visits had lower caries indexes (1.76) than children attending them irregularly (2.5) [71]. Meanwhile, the fear of a visit to the dentist is common in society and results from the fact that dentistry is a surgical specialty, and carious disease seems impossible to avoid [72,73]. Our results confirm the thesis about the reluctance to attend regular meetings with the dentist. It was declared by only $57 \%$ of teenagers we examined, and almost every fifth (18.6\%) visited the dentist only out of pain or a visible cavity. This is also confirmed by the Dudek study [41], in which over half of junior high school students (58.0\%) visited the dentist every 6 months, and $17.4 \%$ of children visited a dentist only in the case of acute pain. The mean examination interval of youths below 17-years-old in Finland was 1 year, while in New Zealand, 79.9\% of adolescents reported having visited a dentist during the last year [74,75].

\section{Conclusions}

Since the dental status of 15-year-old teenagers in Poland is characterized by high values of the DMFT index, it is necessary to implement effective prevention and recovery programs. Health promotion focusing on oral hygiene behaviors should be disseminated more widely because lower caries experience was demonstrated in teenagers declaring tooth brushing after their last meal before bedtime and the daily use of dental floss. Another important area is the development of multi-sectorial actions aiming at the improvement of dietary habits, due to the fact that almost half of the examined adolescents declared daily consumption of sweets.

Author Contributions: Data curation, M.M., J.J.-O.; M.S.; formal analysis, K.K.; funding acquisition, M.M.; investigation, M.M.; J.J.-O.; M.S.; methodology, M.M.; J.J.-O.; M.S.; T.O.; project administration, M.M.; J.J.-O.; supervision, T.O.; writing—original draft, M.M.; J.J.-O.; M.S.; K.K.; T.O. All authors have read and agreed to the published version of the manuscript.

Funding: The study was funded by the statutory budget of the Department of Hygiene and Epidemiology in Pomeranian Medical University, Szczecin. 
Institutional Review Board Statement: The study was conducted according to the guidelines of the Declaration of Helsinki, and approved by the Pomeranian Medical University in Szczecin Bioethics Committee-decision reference No. KB-0012/81/14. Informed consent was obtained from all subjects involved in the study as well as their guardians.

Informed Consent Statement: Informed consent was obtained from all subjects involved in the study as well as their guardians.

Conflicts of Interest: The authors declare no conflict of interest.

\section{References}

1. Listl, S.; Galloway, J.; Mossey, P.A.; Marcenes, W. Global Economic Impact of Dental Diseases. J. Dent. Res. 2015, 94, 1355-1361. [CrossRef]

2. Fejerskov, O. Changing Paradigms in Concepts on Dental Caries: Consequences for Oral Health Care. Caries Res. 2004, 38, 182-191. [CrossRef] [PubMed]

3. Northridge, M.E.; Schrimshaw, E.W.; Estrada, I.; Greenblatt, A.P.; Metcalf, S.S.; Kunzel, C. Intergenerational and Social Interventions to Improve Children's Oral Health. Dent. Clin. N. Am. 2017, 61, 533-548. [CrossRef]

4. Marja-Leena, M.; Paivi, R.; Sirkka, J.; Ansa, O.; Matti, S. Childhood caries is still in force: A 15-year follow-up. Acta Odontol. Scand. 2008, 66, 189-192. [CrossRef]

5. Dahlen, G.; Fejerskov, O.; Manji, F. Current concepts and an alternative perspective on periodontal disease. BMC Oral Health 2020, 20, 235. [CrossRef] [PubMed]

6. De Silva, A.M.; Hegde, S.; Akudo Nwagbara, B.; Calache, H.; Gussy, M.G.; Nasser, M.; Morrice, H.R.; Riggs, E.; Leong, P.M.; Meyenn, L.K.; et al. Community-based population-level interventions for promoting child oral health. Cochrane Database Syst. Rev. 2016, 15, CD009837. [CrossRef]

7. Giacaman, R.A. Sugars and Beyond. The Role of Sugars and the Other Nutrients and Their Potential Impact on Caries. Oral Dis. 2018, 24, 1185-1197. [CrossRef] [PubMed]

8. Moynihan, P.J.; Kelly, S.A. Effect on caries of restricting sugars intake: Systematic review to inform WHO guidelines. J. Dent. Res. 2014, 93, 8-18. [CrossRef]

9. Hujoel, P.P.; Lingstrom, P. Nutrition, dental caries and periodontal disease: A narrative review. J. Clin. Periodontol. 2017, 44, 79-84. [CrossRef]

10. Soares, R.C.; da Rosa, S.V.; Moysés, S.T.; Rocha, J.S.; Bettega, P.V.C.; Werneck, R.I.; Moysés, S.J. Methods for prevention of early childhood caries: Overview of systematic reviews. Int. J. Paediatr. Dent. 2020. [CrossRef]

11. Aspinall, S.R.; Parker, J.K.; Khutoryanskiy, V.V. Oral care product formulations, properties and challenges. Colloids Surf. B Biointerfaces 2021, 200, 111567. [CrossRef]

12. Ministry of Health. Monitoring of Oral Health in Polish Population. Available online: https://www.gov.pl/web/zdrowie/ monitorowanie-stanu-zdrowia-jamy-ustnej-populacji-polskiej-w-latach-2016-2020 (accessed on 15 January 2021).

13. Olszowski, T.; Milona, M.; Janiszewska-Olszowska, J.; Safranow, K.; Skonieczna-Zydecka, K.; Walczak, A.; Sikora, M.; Chlubek, D.; Madlani, A.; Adler, G. The lack of association between FCN2 gene promoter region polymorphisms and dental caries in Polish children. Caries Res. 2017, 51, 79-84. [CrossRef]

14. Ismail, A.I. Visual and visuo-tactile detection of dental caries. J. Dent. Res. 2004, 83, 56-66. [CrossRef] [PubMed]

15. Vieira, A.R.; Marazita, M.L.; Goldstein-McHenry, T. Genome-wide scan finds suggestive caries loci. J. Dent. Res. 2008, 87, 435-439. [CrossRef]

16. Bratthl, D. Introducing the Significant Caries lndex together with a proposal for a new global oral health goal for 12 -year-olds. Int. Dent. J. 2000, 50, 378-384. [CrossRef]

17. Pezzullo, J.C. Logistic Regression. Available online: http:/ / statpages.info/logistic.html (accessed on 15 January 2021).

18. Brukiene, V.; Aleksejūniene, J. An overview of oral health promotion in adolescents. Int. J. Paediatr. Dent. 2009, 19, 163-171. [CrossRef] [PubMed]

19. Tolvanen, M.; Anttonen, V.; Mattila, M.L.; Hausen, H.; Lahti, S. Influence of children's oral health promotion on parents behaviours, attitudes and knowledge. Acta Odontol. Scand. 2016, 74, 321-327. [CrossRef]

20. Tolvanen, M.; Lahti, S.; Poutanen, R.; Seppä, L.; Pohjola, V.; Hausen, H. Changes in children's oral health-related behavior, knowledge and attitudes during a 3.4-yr randomized clinical trial and oral health-promotion program. Eur. J. Oral Sci. 2009, 117, 390-397. [CrossRef] [PubMed]

21. Gaszyńska, E.; Wierzbicka, M.; Marczak, M.; Szatko, F. Thirty years of evolution of oral health behaviours and dental caries in urban and rural areas in Poland. Ann. Agric. Environ. Med. 2014, 21, 557-561. [CrossRef]

22. Milona, M.; Szych, Z.; Olszowski, T. Professional Oral Prophylactic Procedures in Different Oral Health Care Systems Performed in High Caries-Risk Groups of Children on the Basis of the Study in Malmö, Szczecin and Athens. Dent. Med. Probl. 2014, 51, 318-329. (In Polish)

23. Jodkowska, E.; Wierzbicka, M.; Struzycka, I.; Rusyan, E. Polish public programme of dental caries prevention in children aged 6, 12 and 18 years in 2012. Przegl. Epidemiol. 2014, 68, 45-52. [PubMed] 
24. Olczak-Kowalczyk, D.; Kaczmarek, U.; Kawala, B.; Bachanek, T.; Zadurska, M.; Gozdowski, D. Oral Health Monitoring. Monitoring of Oral Health Status of Polish Population in 2013-2015. Evaluation of Oral Health Status and Its Conditioning in Polish Population at Age of 3, 10 and 15; Medical University of Warsaw Press: Warsaw, Poland, 2015; ISBN 978-83-7637-378-2. (In Polish)

25. Małkiewicz, E.; Wierzbicka, M.; Szatko, F.; Strużycka, I.; Ganowicz, M.; Zawadziński, M.; Rusyan, E. Oral Health Monitoring. Oral Health Status and Its Conditionings, and Preventive Therapeutic Needs in 6-and 12-Year-Old Children, and Adults at the Age 35-44 Years; 19 National Epidemiological Survey 2011; Ministry of Health: Warsaw, Poland, 2010; ISBN 978-83-7637-188-7. (In Polish)

26. Pitts, N.; Chadwick, B.; Anderson, T. Report 2: Dental Disease and Damage in Children England, Wales and Northern Ireland. Children's Dental Health Survey 2013. Available online: National Statistics Office. 2015. Available online: https://www.mah.se/ CAPP/Country-Oral-Health-Profiles/EURO/Germany/Oral-Diseases/Dental-Caries/ (accessed on 15 January 2021).

27. Kramer, A.C.; Hakeberg, M.; Petzold, M.; Östberg, A.L. Demographic factors and dental health of Swedish children and adolescents. Acta Odontol. Scand. 2016, 74, 178-185. [CrossRef] [PubMed]

28. Vernazza, C.R.; Rolland, S.L.; Chadwick, B.; Pitts, N. Caries experience, the caries burden and associated factors in children in England, Wales and Northern Ireland 2013. Br. Dent. J. 2016, 221, 315-320. [CrossRef]

29. Waltimo, T.; Menghini, G.; Weber, C.; Kulik, E.M.; Schild, S.; Meyer, J. Caries experience in 7-, 12-, and 15-year-old schoolchildren in the canton of Basel-Landschaft, Switzerland, from 1992 to 2011. Community Dent. Oral Epidemiol. 2016, 44, 201-208. [CrossRef] [PubMed]

30. Melo, P.; Ferreira, C.S.; Nogueira, P.; Calado, R. Trends on the Prevalence and Severity of Dental Caries in Portuguese Children and Teenagers. Caries Res. 2016, 50, 201.

31. Oulis, C.J.; Tsinidou, K.; Vadiakas, G.; Mamai-Homata, E.; Polychronopoulou, A.; Athanasouli, T. Caries prevalence of 5, 12 and 15-year-old Greek children: A national pathfinder survey. Community Dent. Health 2012, 29, 29-32. [CrossRef]

32. Baciu, D.; Danila, I.; Balcos, C.; Gallagher, J.E.; Bernabé, E. Caries experience among Romanian schoolchildren: Prevalence and trends 1992-2011. Community Dent. Health 2015, 32, 93-97.

33. Ivanisevic, Z.; Uzarevic, Z.; Lesic, S.; Vcev, A.; Matijevic, M. Oral Health of Children from the SOS Children's Village in Croatia. Int. J. Environ. Res. Public Health 2021, 18, 616. [CrossRef]

34. Oral Health Country/Area Profile Project. Available online: https://capp.mau.se/country-areas / (accessed on 18 January 2021).

35. Guideline: Sugars Intake for Adults and Children; World Health Organization: Geneva, Switzerland, 2015; Available online: http://www.who.int/nutrition/publications/guidelines/sugars_intake/en/ (accessed on 15 January 2021).

36. Moynihan, P.; Makino, Y.; Petersen, P.E.; Ogawa, H. Implications of WHO Guideline on Sugars for dental health professionals. Community Dent. Oral Epidemiol. 2018, 46, 1-7. [CrossRef]

37. Explore Oral Health. Available online: https://www.mah.se/CAPP/Globalsugar/Sugar-Global-Data/Sugar-ConsumptionEURO/ (accessed on 15 January 2021).

38. Skalsky Jarkander, M.; Grindefjord, M.; Carlstedt, K. Dental erosion, prevalence and risk factors among a group of adolescents in Stockholm County. Eur. Arch. Paediatr. Dent. 2018, 19, 23-31. [CrossRef]

39. Provatenou, E.; Kaklamanos, E.G.; Kevrekidou, A.; Kosma, I.; Kotsanos, N. Erosive Tooth Wear and Related Risk Factors in 8- and 14-Year-Old Greek Children. Caries Res. 2016, 50, 349-362. [CrossRef] [PubMed]

40. Tahmassebi, J.F.; Duggal, M.S.; Malik-Kotru, G.; Curzon, M.E. Soft drinks and dental health: A review of the current literature. J. Dent. 2006, 34, 2-11. [CrossRef]

41. Dudek, M.; Turska-Szybka, A.; Soika, I.; Gozdowski, D.; Olczak-Kowalczyk, D. Factors influencing oral health behaviors of 15-year-olds from Mazowieckie Province. Stomatol. Wsp. 2017, 3, 8-15.

42. Regulation of the Minister of Health of 26 August 2015 on Groups of Foodstuffs Intended for Sale to Children and Adolescents in Units of the Education System and the Requirements That Must Be Met by Foodstuffs Used for Mass Catering for Children and Adolescents in These Units. Dz.U. 2015 poz. 1256. Available online: http://prawo.sejm.gov.pl/isap.nsf/DocDetails.xsp?id= WDU20150001256 (accessed on 6 July 2018).

43. Regulation of the Minister of Health of 26 July 2016 on Groups of Foodstuffs Intended for Sale to Children and Adolescents in Units of the Education System and Requirements That Must Be Met by Foodstuffs Used as Part of Mass Catering for Children and Adolescents in These Units. Dz.U. 2016 poz. 1154. Available online: http://prawo.sejm.gov.pl/isap.nsf/DocDetails.xsp?id= WDU20160001154 (accessed on 6 July 2018).

44. Chapple, I.L.C.; Bouchard, P.; Cagetti, M.G.; Campus, G.; Carra, M.-C.; Cocco, F.; Nibali, L.; Hujoel, P.; Laine, M.L.; Lingstrom, P.; et al. Interaction of lifestyle, behaviour or systemic diseases with dental caries and periodontal diseases: Consensus report of group 2 of the joint EFP/ORCA workshop on the boundaries between caries and periodontal diseases. J. Clin. Periodontol. 2017, 44 (Suppl. 18), 39-51. [CrossRef]

45. Mattila, M.L.; Tolvanen, M.; Kivela, J.; Pienihakkinen, K.; Lahti, S.; Merne-Grafstro, M. Oral health-related knowledge, attitudes and habits in relation to perceived oral symptoms among 12-year-old school children. Acta Odontol. Scand. 2016, 74, 343-347. [CrossRef] [PubMed]

46. Mulic, A.; Skudutyte-Rysstad, R.; Tveit, A.B.; Skaare, A.B. Risk indicators for dental erosive wear among 18-yr-old subjects in Oslo, Norway. Eur. J. Oral Sci. 2012, 120, 531-538. [CrossRef]

47. Sheiham, A.; James, W.P.J. Diet and Dental Caries: The Pivotal Role of Free Sugars Reemphasized. Dent. Res. 2015, 94, 1341-1347. [CrossRef] [PubMed] 
48. Scientific Advisory Committee on Nutrition. Carbohydrates and Health 2015. Available online: https://www.gov.uk/ government/publications/sacn-carbohydrates-and-health-report (accessed on 16 January 2021).

49. Holmes, R.D. Tooth brushing frequency and risk of new carious lesions. Evid. Based Dent. 2016, 17, 98-99. [CrossRef]

50. Zimmermann, H.; Zimmermann, N.; Hagenfeld, D.; Veile, A.; Kim, T.S.; Becher, H. Frequency of tooth brushing a risk factor for periodontitis? A systematic review and meta-analysis. Community Dent. Oral Epidemiol. 2015, 43, 116-127. [CrossRef]

51. Sambunjak, D.; Nickerson, J.W.; Poklepovic, T.; Johnson, T.M.; Imai, P.; Tugwell, P.; Worthington, H.V. Flossing for the management of periodontal diseases and dental caries in adults. Cochrane Database Syst. Rev. 2011, 7, CD008829. [CrossRef] [PubMed]

52. Julihn, A.; Barr Agholme, M.; Grindefjord, M.; Modeer, T. Risk factors and risk indicators associated with high caries experience in Swedish 19-year-olds. Acta Odontol. Scand. 2006, 64, 267-273. [CrossRef] [PubMed]

53. Davies, R.M.; Davies, G.M.; Ellwood, R.P. Prevention. Part 4: Toothbrushing: What advice should be given to patients? Br. Dent. J. 2003, 195, 135-141. [CrossRef]

54. Nordström, A.; Birkhed, D. Attitudes and behavioural factors relating to toothbrushing and the use of fluoride toothpaste among caries-active Swedish adolescents-A questionnaire study. Acta Odontol. Scand 2017, 75, 483-487. [CrossRef]

55. Levin, K.A.; Nicholls, N.; Macdonald, S.; Dundas, R.; Douglas, G.V.A. Geographic and socioeconomic variations in adolescent toothbrushing: A multilevel cross-sectional study of 15 year olds in Scotland. J. Public Health 2015, 37, 107-115. [CrossRef] [PubMed]

56. Vašíčková, J.; Hollein, T.; Sigmundová, D.; Honkala, S.; Pavelka, J.; Kalman, M. Trends in Children's Toothbrushing in the Czech Republic from 1994 to 2014: Results of the HBSC Study. Cent. Eur. J. Public Health 2017, 25 (Suppl. 1), 57-59. [CrossRef]

57. Ceinos, R.; Bertrand, M.F.; Cucchi, C.; Lupi, L. Hierarchizing caries risk factors among first-year university students in Nice (France): A cross-sectional study. BMC Oral Health 2017, 17, 159. [CrossRef] [PubMed]

58. Montero, J.; Costa, J.; Bica, I.; Barrios, R. Caries and quality of life in portuguese adolescents: Impact of diet and behavioural risk factors. J. Clin. Exp. Dent. 2018, 10, 218-223. [CrossRef] [PubMed]

59. Skinner, J.; Johnson, G.; Blinkhorn, A.; Byun, R. Factors associated with dental caries experience and oral health status among New South Wales adolescents. Aust. N. Z. J. Public Health 2014, 38, 485-489. [CrossRef] [PubMed]

60. Honkala, S.; Vereecken, C.; Niclasen, B.; Honkala, E. Trends in toothbrushing in 20 countries/regions from 1994 to 2010. Eur. J. Public Health 2015, 25 (Suppl. 2), 20-23. [CrossRef] [PubMed]

61. Kritsotakis, G.; Psarrou, M.; Vassilaki, M.; Androulaki, Z.; Philalithis, A.E. Gender differences in the prevalenceand clustering of multiple health risk behaviours in young adults. J. Adv. Nurs. 2016, 72, 2098-2113. [CrossRef]

62. Mazur, J. Health and Health Behavior of Children and Youth in Poland Compared to Selected Sociodemographic Conditions. The Results of the HBSC 2014 Research; Mother and Child Institute: Warsaw, Poland, 2015; pp. 156-161. (In Polish)

63. Król, M.; Grobelny, M. Knowledge of children and adolescents from the Lublin Province on the use of oral hygiene aids in dental caries prevention. Med. Og Nauk Zdr. 2014, 20, 335-340. (In Polish) [CrossRef]

64. Iwanicka-Grzegorek, E.; Michalik, J.; Zapalska, K. The level of knowledge about caries and its prevention among junior high schools pupils. Nowa Stom 2010, 1, 3-8. (In Polish)

65. Polk, D.E.; Weyant, R.J.; Manz, M.C. Socioeconomic factors in adolescents' oral health: Are they mediated by oral hygiene behaviors or preventive interventions? Community Dent. Oral Epidemiol. 2010, 38, 1-9. [CrossRef]

66. Jimenez, R.; Tapias-Ledesma, M.A.; Gallardo-Pino, C.; Carrasco, P.; de Miguel Madrid, A. Influence of sociodemographic variables on use of dental service, oral health and oral hygiene among Spanish children. Int. Dent. J. 2004, 54, 187-192. [CrossRef]

67. Savage, M.F.; Lee, J.; Kotch, J.; Vann, W.F. Early preventive dental visit: Effects on subsequent utilisation and costs. Pediatrics 2004, 114, 418-423. [CrossRef]

68. Menegaz, A.M.; Silva, A.E.R.; Cascaes, A.M. Educational interventions in health services and oral health: Systematic review. Rev. Saude Publica 2018, 52, 52. [CrossRef]

69. Soussou, R.; Aleksejūnienè, J.; Harrison, R. Waiting room time: An opportunity for parental oral health education. Can. J. Public Health 2017, 108, 251-256. [CrossRef] [PubMed]

70. Al-Rafee, M.A. The epidemiology of edentulism and the associated factors: A literature Review. J. Family Med. Prim. Care 2020, 9, 1841-1843. [CrossRef] [PubMed]

71. Carrillo-Diaz, M.; Crego, A.; Armfield, J.M.; Romero, M. Dental fear-related cognitive vulnerability perceptions, dental prevention beliefs, dental visiting, and caries: A cross-sectional study in Madrid (Spain). Community Dent. Oral Epidemiol. 2015, 43, 375-384. [CrossRef]

72. Pohjola, V.; Lahti, S.; Vehkalahti, M.M.; Tolvanen, M.; Hausen, H. Association between dental fear and dental attendance among adults in Finland. Acta Odontol. Scand. 2007, 65, 224-230. [CrossRef]

73. Armfield, J.M.; Spencer, A.J.; Stewart, J.F. Dental fear in Australia: Who's afraid of the dentist? Australian Dental J. 2006, 51, 78-85. [CrossRef] [PubMed]

74. Linden, J.; Josefsson, K.; Widström, E. Frequency of visits and examinations in the Public Dental Service in Finland-A retrospective analysis, 2001-2013. BMC Oral Health 2017, 17, 138. [CrossRef] [PubMed]

75. Børsting, T.; Stanley, J.; Smith, M. Factors influencing the use of oral health services among adolescents in New Zealand. N. Z. Dent. J. 2015, 111, 49-57. [PubMed] 